研桃の其のはまきをる般藥 究得を他能何て、は减所に用 せへはのにがに本少な認植 己き果部す成云邦すり め物 めのし分へ分はにる例ら少 らみて蚁きに扟於にへ当有 れな淇果處畧つては汸了効緒 たら成しに同了はb芳の成 るず分てあるあ培て香み分言

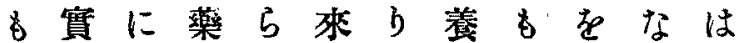
其際哄用ざす然品此有ら培 目上同にれ原らはこすすす養 的にな堪ご因ば殆こる叉植 實於き八るこ培ごは野座物 にてやざ或な養效其生地中 此る否る植る品力一植にに 處㕛やや物かには端物上於 に頗を否の此はくををるけ 存る研や或等何只琵移 す必究又部の故㒖 知之多よ 令要す同分問に加すて少り 此なる一方題有にる培のる 處りは、種現を効北に養異却 に長物屬に解成海足す同て 報井にな醫决分道るるる あ野 告博化る藥す少產又をる生 す士りるにるなは彼るこの るのて西供はる少のはと光 本余は洋せ難かと却るす

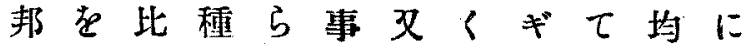

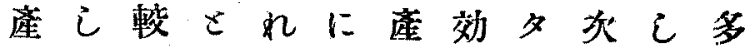
莨て 的日つし 地力り第くき 若裳容本了てにをスに認こ

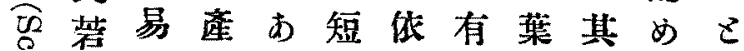
㝵草にのる日り学の芳らは

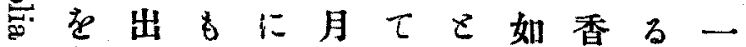

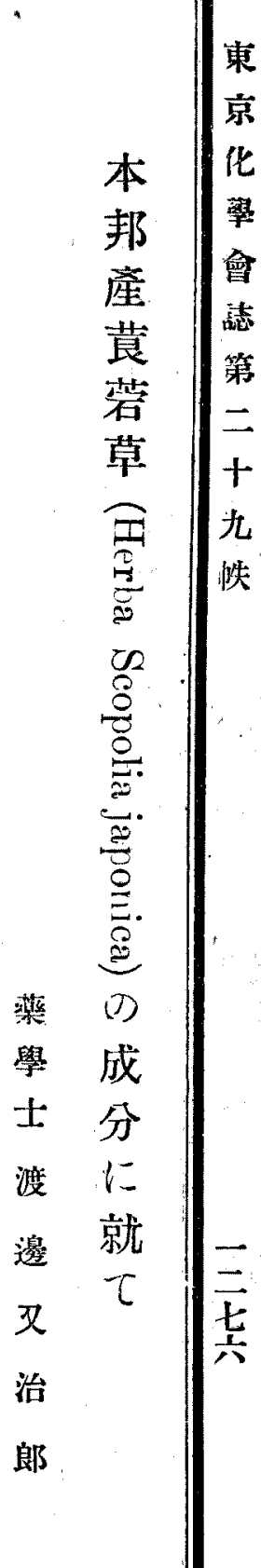




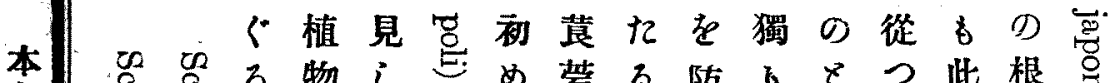

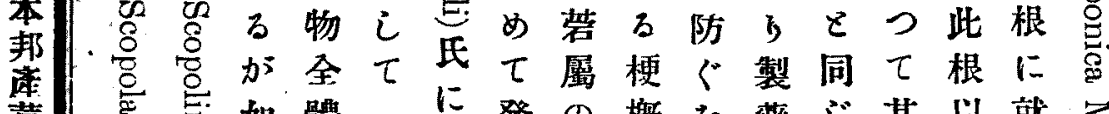

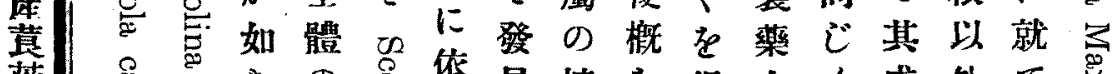

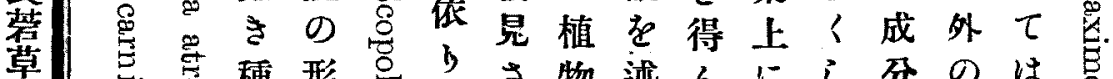

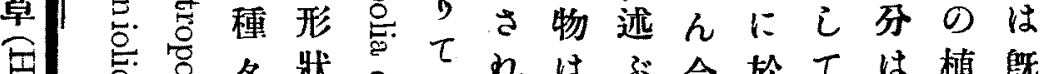

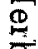

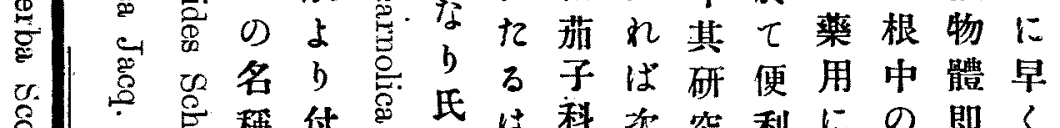
8

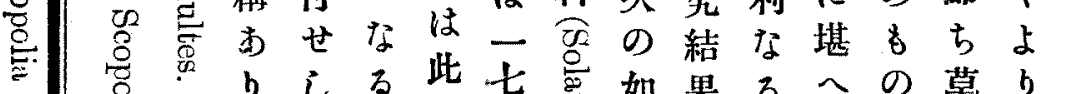
产 管

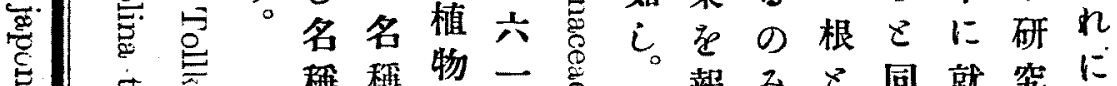

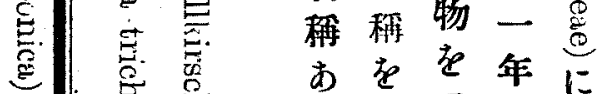
の

分落

就 あをを年に $b$ 付 $r$ 䨞 即 せ

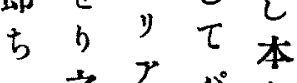
出之海 だ 邦 $\tau$ 報みを同就究に 告な並ごて せ良 すら用きはら了 万新彼れ相 に又得否我七類 臨根亏 共了似 み邑加知に結す 此掘或れ未果了 植りはざ゙根歐 物て少る之は洲 に濑くるれ現產 就次与若をに蕞。 七植他已研醫蓉 之物 物 其究藥 让を成報に务 ま絕代分告供志 で隇用にせせ

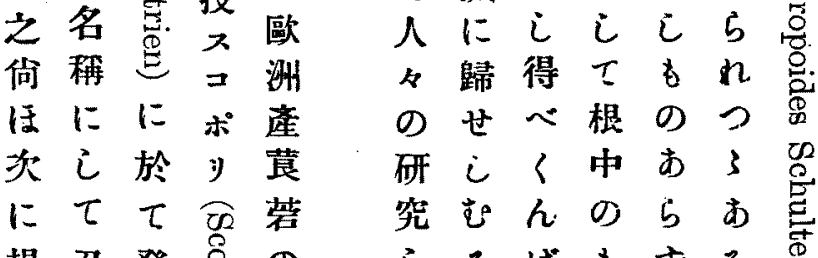

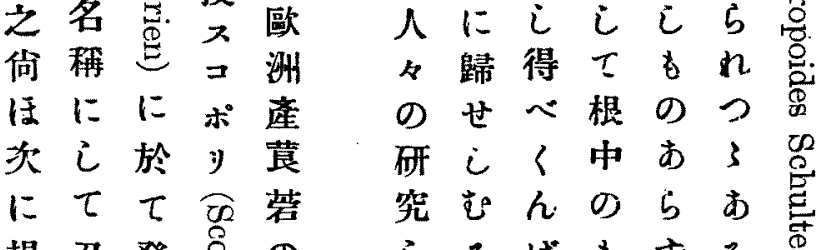

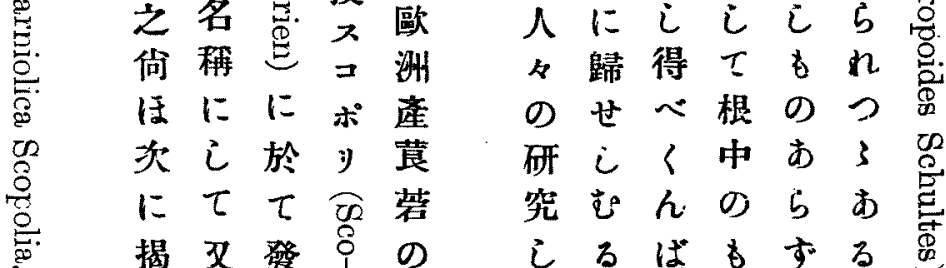

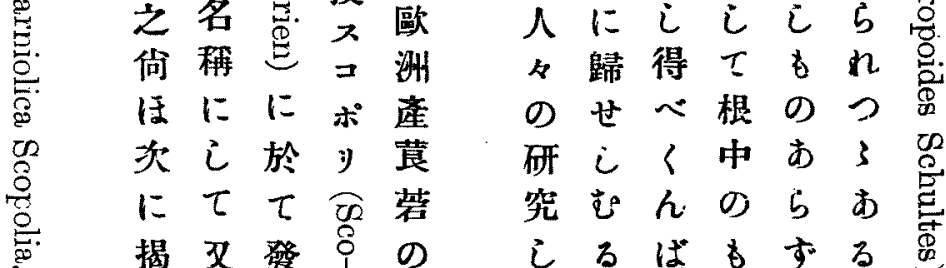
揭文發门 こるばるする 
含了本要究所总袁な令此

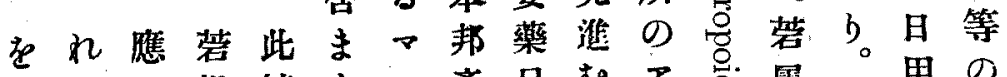
舍 有るせは物方莨こにN道中 ひ名 化 ここら日はてン整な從カ友從 子心る本弗 ジ令根るつロび承 はラ故醫子ラ密ににてイ本醫 結トにに科二氖就至之ト邦藥 晶ン又依にン氏てれよ類產の 形ナ此引屬妿に初り。马区莨料

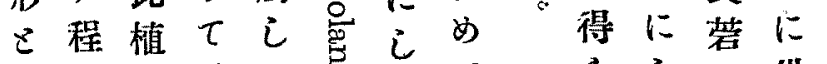
¿に物 歐 $\tau$ 总 $\tau \tau$ ら $\tau$ 根 供 て 磨は洲气研れてた 其睡日醫害公究た生异ら

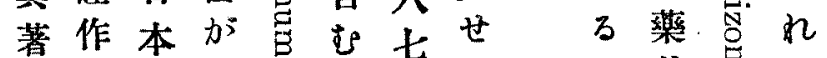

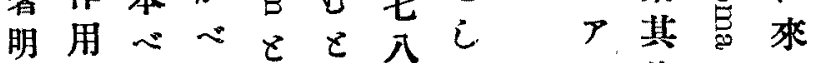
量なルル㴔的り を! 量はラ突世頃令 得且ドド密り古の 且つンンを其 $b$ 德 つアナナの當氏生 特卜合根中時は試 異口密間の此驗 の ピ 悹空に報根所 ・ゾン悹位告中の ラを芯氖すはに前 二含密兽之次户身 ン有产总れのトた 反世吉兽が如口る 礁ず鬼を篇しど司 をしと用め。䒚 認ておにに㙋 めデ呼る た $b=3<$ 產 佾ン然に莨をた

力 \& 8

- 應导

人用峞

誤

ドせ 燰は

氏

特 5 总 特

にれに 大的鬼歐

$=$ 万洲

机こ此產

亏 こ等蕞

ミをの蓉

ン間 根 根

のかよ 如ず り 矛.

き而得曽

はn 5 品

紀

愈付

の

is 5

$\frac{2}{8} x$

晋

又名

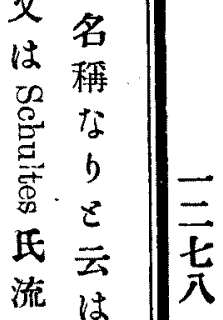

の 3

设

㿽

: 612

重研万兽 
本 $\neq$ レ樹卜濃鹽よマな怒本、に此

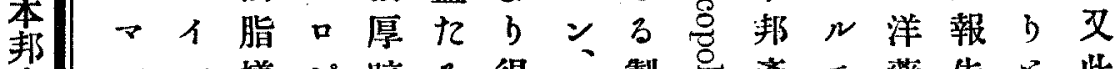

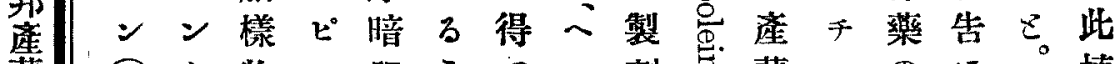

莫国を物ン褐をてン劑导莨ンのに植

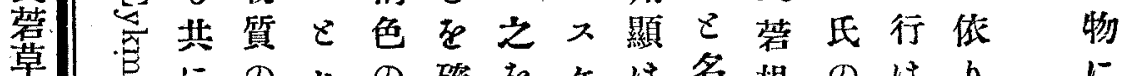

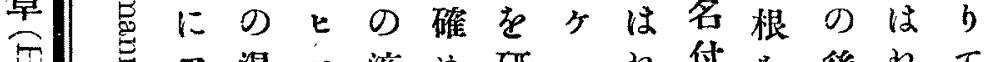

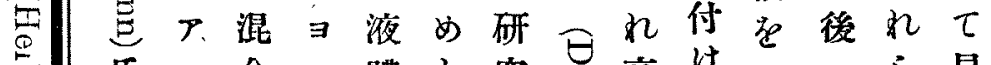

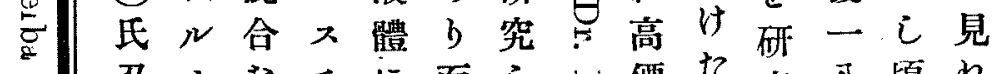

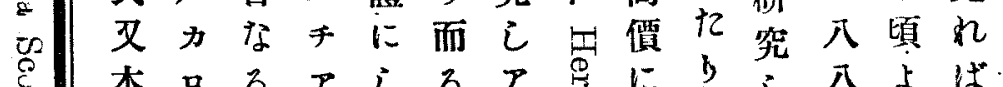

量 本

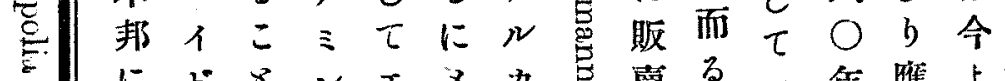

しにトをンメヌカ賣るた年應よ

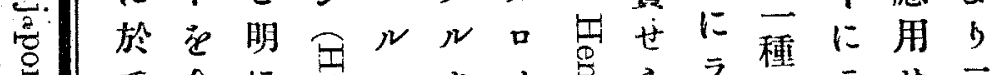

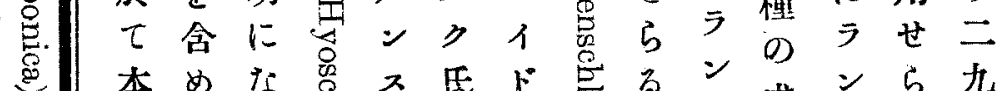

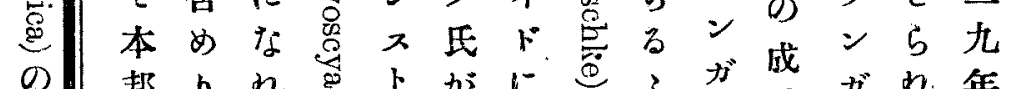

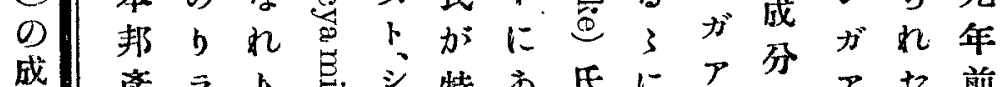

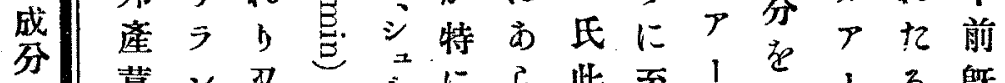

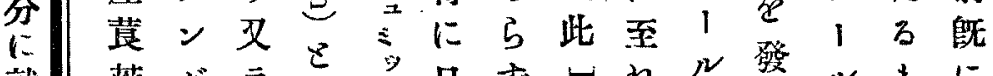

就宕

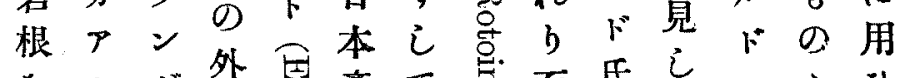

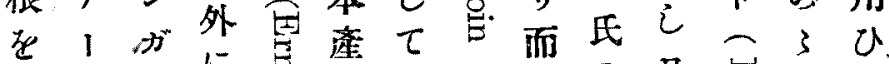
研ルノに量莨炭なる

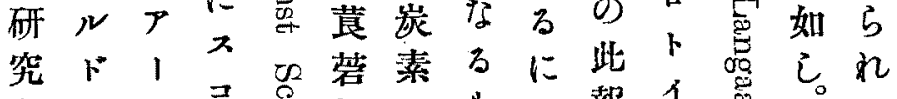

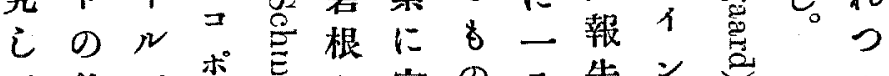
て後ドポ突よ富の八告ン包了

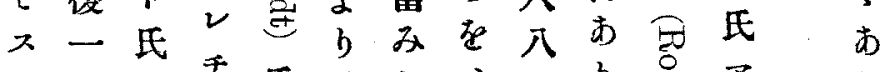

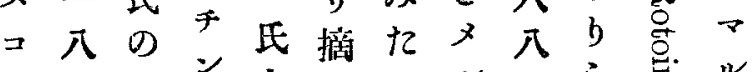

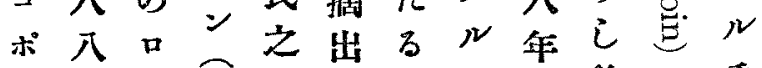

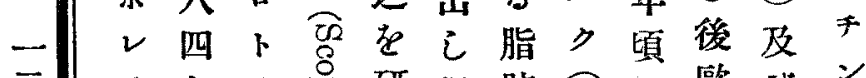

三人年1害研得肪国に歐び

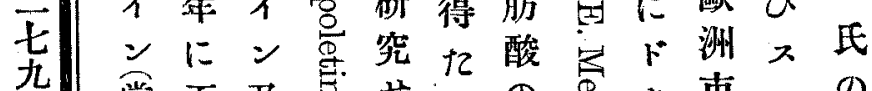
當至及导世るの悬》市子の 時りびのるるア运卜㩐术法 氏てス多結等氐止にに

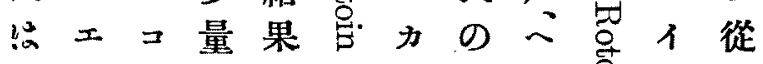

特

黑

广

る

=

$\varepsilon$

は

他

植

物

見 \% te 得 ざ 3 $z^{\circ}$ 强 E t 以 $\tau$

見 n $<$ 溃 石 剩 te 放 本 既、ポをアはリ所ル导ンひ 
最ミ口は得又を移後ンチ此をのに す四パ分てクををパ是ン與入發配此

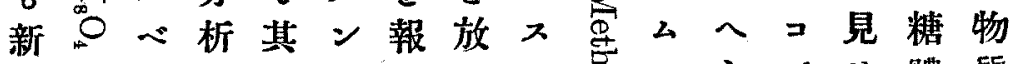
しおルの物ッ告つキ㝴卜しポせ體質

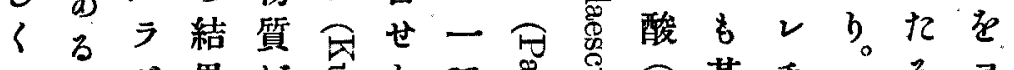

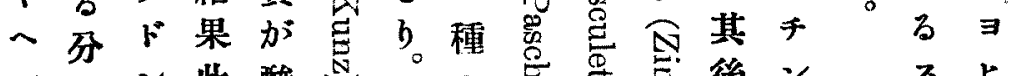

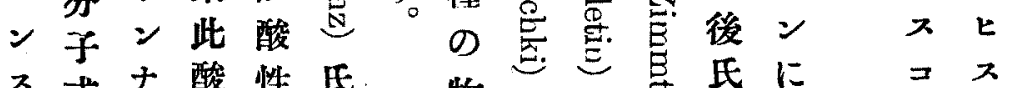

ス式ナ酸性氏 ヶによにをる

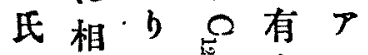
本當得出す十

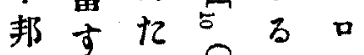
產る $\begin{array}{llll}9 & 0 & 1 & 0\end{array}$ 莨こ䖝なる 蓉巨石了しル 根を箖分てう よ報を子わト b告放式yン 得せつ皆 スナ 七物與 $>$ 草 る。質へ卜並 入 にb口泟 $=$ 就其 ポ き後酸根 v $\tau に \widehat{0} \emptyset$ 千 研至 $\nu$ 究 $b \underset{2}{2} \neq$ に す. 就 万パ蜜上 $\tau$ 所 $x \stackrel{5}{5} b$ 研娄 $\neq$ 第橫 究 b民民色 $i$; 其再命 $\tau \cdot の ひ ゙$ 名結 此結 $T 己$ 晶 の 果
物氖焉氏に 質物を同突: は就 $\widehat{P}$ 同 总此 $\tau$ 呑卜ざ誘物は

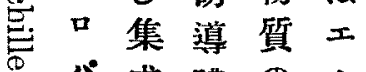
要公成體の 总心河性 $\checkmark v$ 近狀 t实のき 發ドな關エ氏 見ンる係ス之

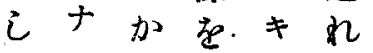

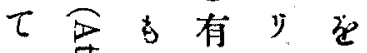
此客知夺分 物送机了 質 票亦所 が

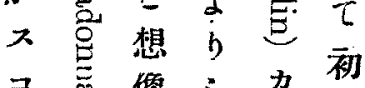

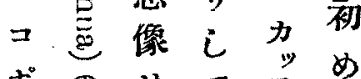
ポせて う $\nu$ 熟る チせこ千酸 ンろを 1 㕰 に果を希号 一實報 致よ告 ス 导了 すbせキ分 b篮 b 2 等子 こ石其 $\neq$ の式
東 京 化 學 會 ポ ) $P$ $\nu$ ミ ठิ 总 $\exists$ 及 び チ 其 ン 分 解 旵 成 总 績 體と た る 混 ᄌ 合 コ ホ5 ᄂ チ $>$ 想 $\vec{\lambda}$ 空 像 总 $\varepsilon-$ 
コシ ス 即 所氏び一リ少 5 又昌高子 ス

カを歺方謂はア體ン量すス音橋式コ

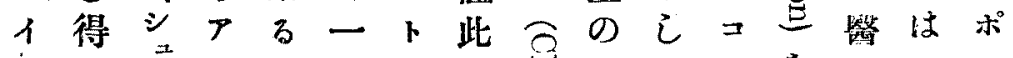

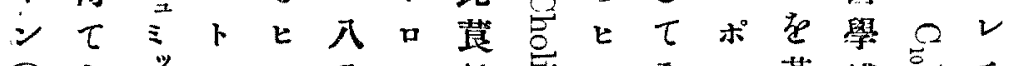

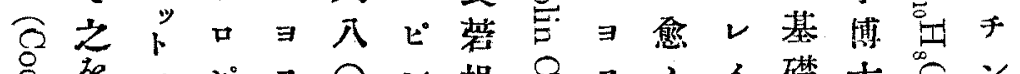

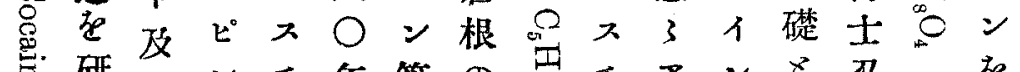

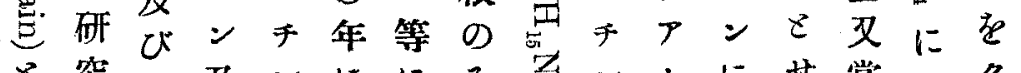

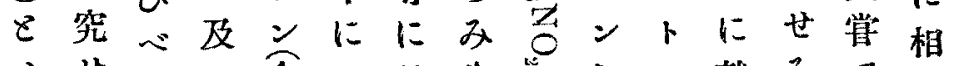
メせンび令七就な就るて當ン 员 \し 总 メ結 ルョ云ス最ず含るンはマスる氏 监果

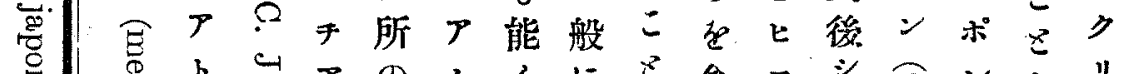
窟 ピ 总ンコこ究子 なン岛とポ科 る及化同ラゲた植 集ミ宕せ志志た

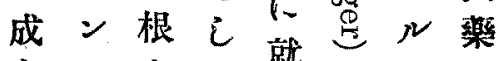
を をる就よ七特

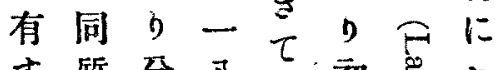

二 主質分八其初产

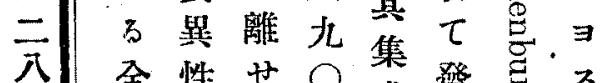

入 全性せ $\bigcirc$ 成發苞入 く體る年を見恕 新な七に导せと 奇らョエ焉るな、 のざスル艺氏るン アるチン 银入

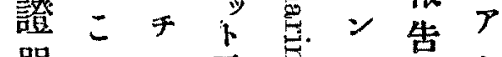

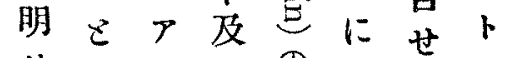
せをミび の 就 乌 ら報ンへ誘て。パ 凡告とン導研、酸 せのス體究 そ 比 之合氏るオ較 机な等こキ计 そるえと 同をををに に 時る研報 ド全 に確究告口 营證 $i$ せ 相 䂟已單引。 根又純 1 致 中時の にと物方 はし質离つ シ $た$ 其 
酸を分瞳次の本兰歐已。斯にり年心

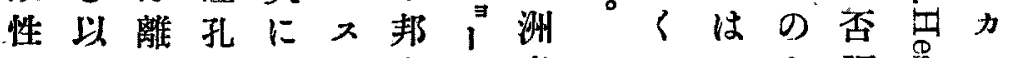
のて 且散尙コ產り㕍 水茄つ大注莨ン莨 溶解 精薬吾 $\ni$ 若及若 液し製の \& ミ根ひ根 をて己純のン中 $の$ 中 烝金而粹記又にコに 發をる製憶ジはポは

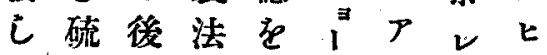

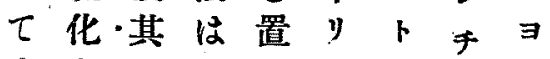

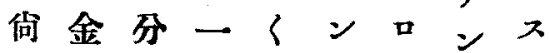
ほ・思離旦心皮ピ。 溶なせ金きびン ア 存已る複こス不

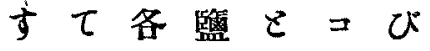
る沈のにはボ 硫澱純 㱍瞳り 化せ粹ざ孔ン ス 水乙金て 散尼 素め複鹽大含 尼て留酸藥む ミ 驅其を含のとン 除水有純已心 己 中 9 粹 $\tau$ 殆 た滤に沸製知 万分湯法 与等 後别布上に方分

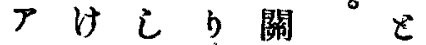
机置再可 力るき結 3

》濾て晶こ 液硫已 以 即化 $\tau$ な $\tau$ 方水互 $b$ 分鹽素に此

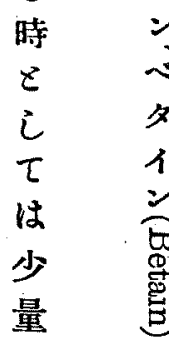

ミ

ข

少

量

の

$>$

r

p

ピ



x

ב

ポ

j

ミ

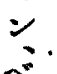

タ

1

产

退.
のマみ認 如 2 小

くダら 5 氏

しラすに尔な

七草比至全る 歐 $\equiv 刃 れ=$ 洲種入 万文 及子于其店存 び及アの氏確 本び么後のめ 邦心不報 萑 $v=$ 至告

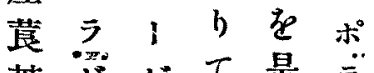
若丞ら゙て是 根ンル䜅: 中ナの に根種占てと 今等子氐合 日に快范名 ま落此罗

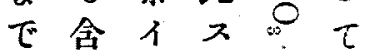
發屯ジコぬ 見こ厂求方兄 せともラ集 万类三成 確 兽:

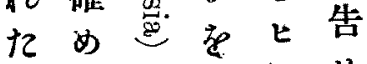
\begin{tabular}{llll}
3 & 3 & 9 & $\Xi$ \\
\hline
\end{tabular} 8 葉洲スり の-中涯千其 はに莨ンの 左 又蓉の後 の 少根存 如量よ在セ
東

京

化 學 율 誌 第 二
九 帙 


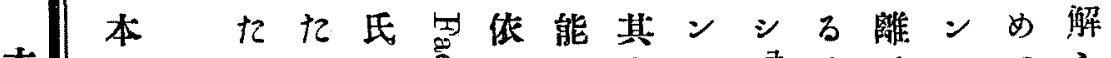

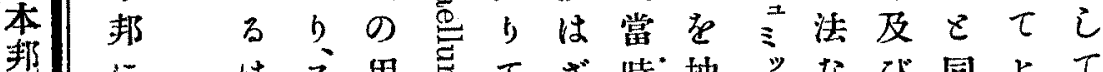

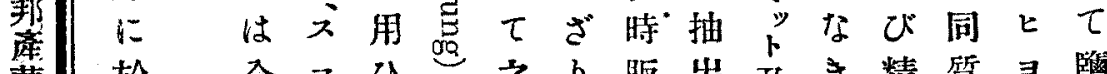

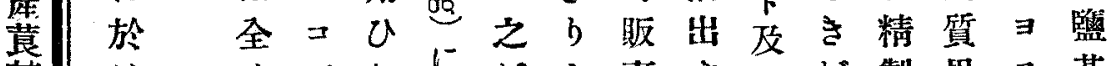
营り、くポたにがし賣すびが製異入基 草当此

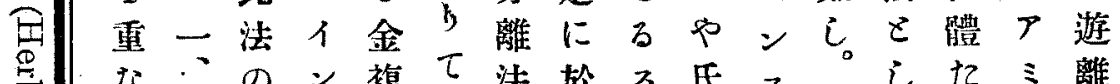
要は・のン複て法於入氏

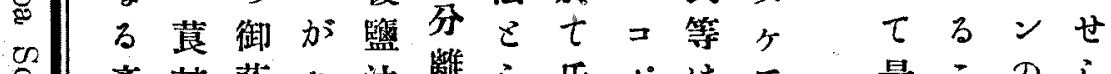

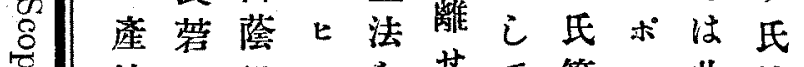

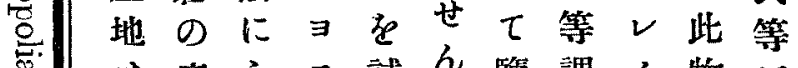
は座己ス試ん監謂イ物方: 密 甲地 $\tau$ チみ酸人ン質工

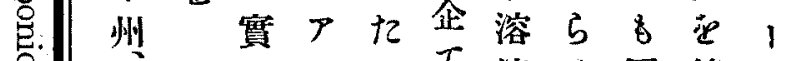
递武にミるて液く同結丰 の州ランにたを之樣晶て 成|のを初吕なれに世ン 分武 デアめす恐舍し氏 就甲 $甲$ 甲 て山品容敗炭は别九に 信 ルピ易に酸單漛を從 州七ンく終力一のてつ の民飞而れ、な物種て

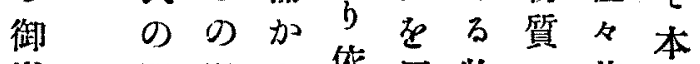
㠇賜混与依用物に苦邦 江物合完 $b$ 質 $己 心$ 心 州な物全 $\tau$ た $て$ 世莨 の b。に贾分非之し蓉

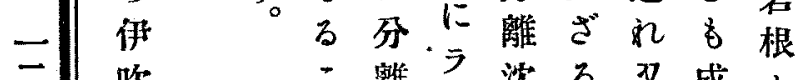
公 吹 父 山 二離 ラ沈了又成占 をす I澱が結功 b 古るデ田第晶世不 に確こン荠なせざコ

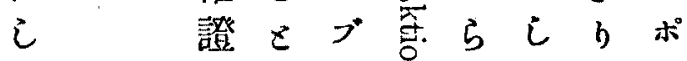
$\tau$

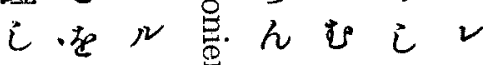
其

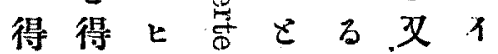

最このし 良己精 む のを製る 結確にに 果定應 あ を己用 b 得得せ此 ねて法 るる方れ のは法る み全にや 小く $i$ 一 与此 $\tau$ ず法氏八 今 $の n^{*} 0$ 日篇 七 年 にめ 至にスラ る己 $\neq 1$ むてアデ 倘瞳ミン ほ孔ンブ 之散のル。 れ大厂 に藥ト氏 優の口品 的分 ヒ初 
次莨果花出圆てセシ哭本他

(二)(一)の宕 實はす。形猍ンォ客邦美 莨莀如草は鍾・尼細チ1 宕宕しを覆狀なとメト亦莨

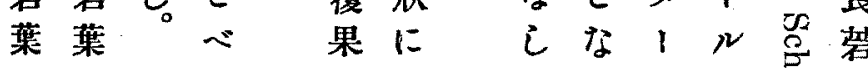

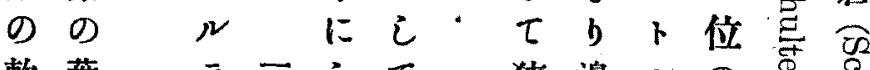

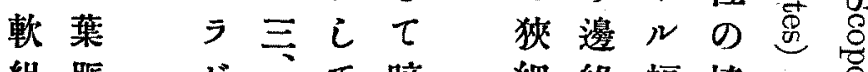
組 脈占、て 暗 織上ン心゙熟紫 に公に市色 は草ラるを 客毛をド後有 莺茸はンヒし 中を能ナヨ暗 に缺、草不色 は如相飞のの 結す。類の果網 晶

細

胞 ze
缺
如
す。 似區實脈 す别のお 万如 9 $8<\tau$ 之菲上 等 下 端

部五 區・の辦 別周に 士 圍分 2 小。

に $b$

泩翕

目狀

す

へ 破

き綻

點 す

は

紬緣幅植に异:

飞波七物能范蕞州

な濤七體く宕若の

b 狀 こを相筑

下来出類号の波 部な⿻已似突形山 は $己 1$ 其 $己$ 宣等

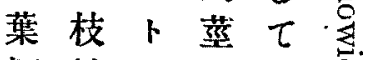
柄梢此の四 太 $に に$ 位下月は 移はを部末既 る大有になに 四小已附 $b$ 前 月二下着五に よ種部せ月 6 りのはるの述

五葉楔葉初へ

月を狀はめた

に連を畉にる

用

至生な圆宿如

供

るす已形根

の此 て、によ歐

際葉潮已b䓑

葉は次七高㡾

腋尖葉長さ莨

より唡き凡㟯

りたに凡そ整

花る沿一三

美

を卵子八デ空 
斈 改

莨 正

营 日

草本

疍

㩰

局

方草心占

용

.

所中

定

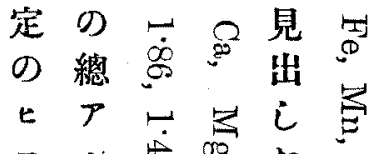

$\exists N$ 离品れ

入力

Ф

成

x

$\neq 1$ 近

管

就

$\tau$

$=$

定

量

de 海

$\forall$ 析

次

$に$

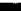

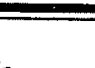


なな

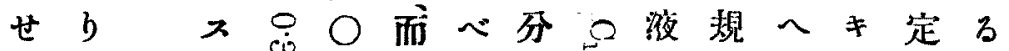

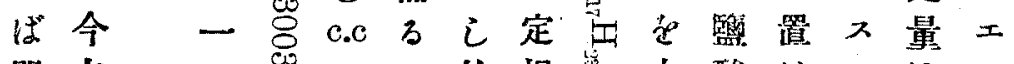

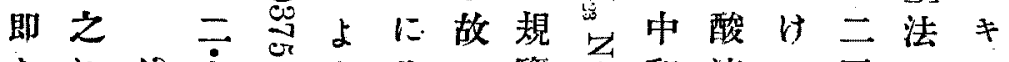

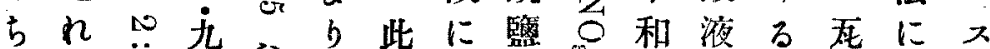

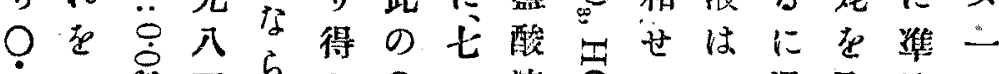

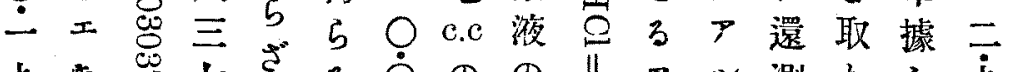

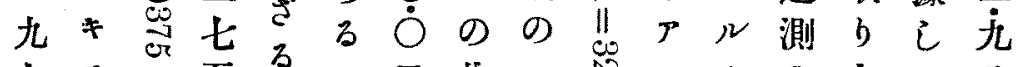

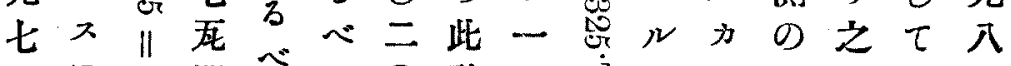
$\% に$ に 即加き○酸 c.c 岕力口祭れ定三

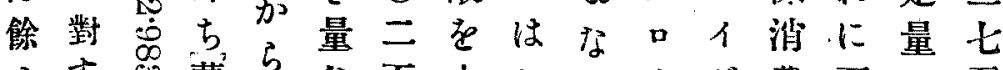
こす莨すな五中心るイド費百せ死

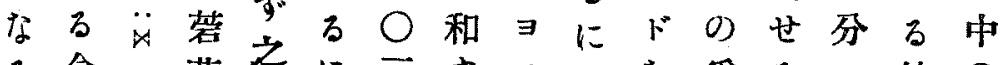
る含草之に三すス依を第る一結の 量一化死々千 b假め百監果總

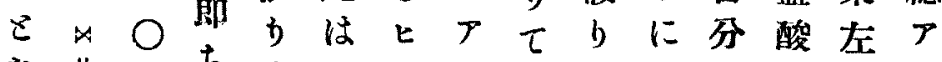
な 11 ○ 全エョミ出に中定液のル

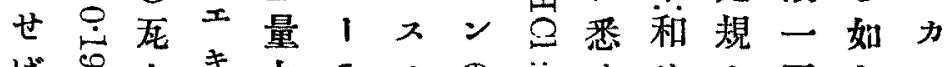

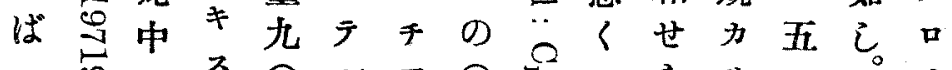
一造のス

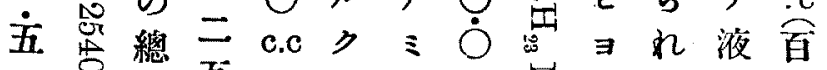
二 $\%$ 过 $\varepsilon$ 力 得 $>$ 量分即 $>$ 量度規

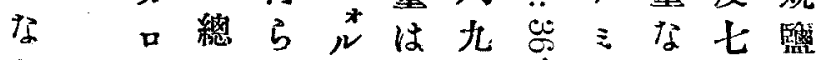
b $1 ア$ 万 莨 ドル゙九㣽七范と令な液 蓉はカき○远琶な此りに

草

に

對

\$

3

含

量

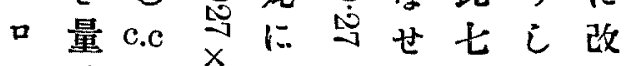

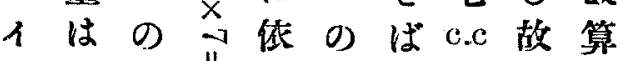
$\vdash 0 \equiv \| \begin{aligned} & \| \\ & 0\end{aligned}$ 比其のに已

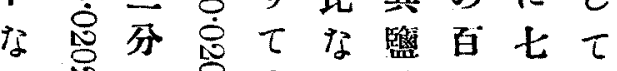

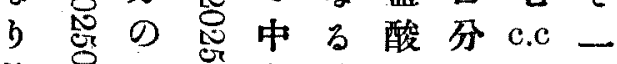

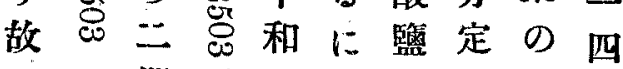
に $\times$ 即死せ依の規百 c.c

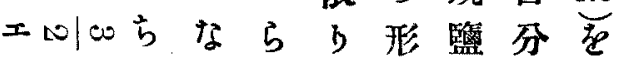
東 京 化 學 會 誌 第 二 $+$ 九 帙 $\varepsilon$ 
本

水已水る 腤

にて 分。水綠

不减。溶色

養 溶少工液の

菇解せきは粘

草分る ス带着

포

蛋

पू.

$\frac{8}{8}$

"

․ㅠㅇㅛ.

の

成

羿

r

就

的量三褐

严五和濃

四り已酸 $\neq$

死故 攝性 ス

をに氏老に

科水一有之

取 分 $\bigcirc$ 方
重三黄力九

丰蛙六色有工

주워

五兰死亡 る

四死科微厚性

二な取に土狀

已江五之

$z-L$

开に

に六於

水五

灰 \% 殆

加に

八相 不

七當 變

攪す。量

拌店

乞 得

濾

過

る

$\$$

i で

其 乾

䄀 $n$

に

水

ze

加

ح

$\tau$

振

湿

己

應

㧒

濾

過

¿

12
す以第温第を第せ研

上三浸二檿一b。究

三回復回搾回。に

回第厴第濾原供

の二搾一過释 せ

浸回濾回す。乾侄

出の過の燥 $の$ 七

濾壁す厴草 キ

過搾 搾

液 殘殘

F

五

ス 研

は究

渻

渣

合に

更

$\tau に$

蒸同

餾上

c 酒

酒 精

精 二

倍

出 重

來量

万放

丈加

に

倍

左用

の $x$

製 ₹

法 ス

に

同

1

にの

优製

酒

万法

其

精

$\equiv$

万丂

製

宝

重九

量

け

餾

取 温

已 浸

$\tau$ 後

濃 壓

厚搾

工濾

* 過

初

め

に

取

b

t2

3

原

料

の

点

造

スす

加

$\Sigma$

勇
八出

$\tau$
-

$\%$

酒

精

を

加

b

犬

短

の

大

日

本

筧

$\tau$

温

浸

後

其

整

株。

武

佥

就:

に

化

液

託 
别分文厂 小倘過工 に離の韭るほしキ

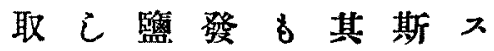
b $\tau$ 酸し沈上のに 置工をて 港よ如少 き1加少を b 工示的生水度方 、少くせを覆了 テをる濃注し水土 $儿$ 蒸後厚にきてを东 乙䬰之を至荎加加 のしれなる洗へへよ 振之にせて涤たてい

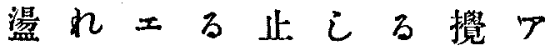
はに後め其水汼 之溶 テ 此其洗がし力 れけル溶濾液最其口

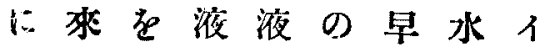
溶b加中を一溷にド けた人の何小濁溶の 來るてア一部せけ抽 ろ物數 ル回をざた出 る質回力滤耿るる の酸振口過 りに部 な性璗人厄て至分 きの之ドてりは に物每を後䗃每 至質回中高 $\because$ 渣回 りを其和か子濾 七不振すら亿濾器 止純盪るざ エ器上 む物 エにる心上に の1十温試に移 混方度藥移乞 合ルなに京して はる。於加て濾
す。故灰舍水了椬 に分むににを 此を 溶一水 の前以解 - に 含のてす市入て 量水之る六洗 は分を部八沙 以色控犁存已 前定除。元て 取量す差り水 りせるに故に たると依に着 百残き b其色 二椬は溶含せ 二一水解量 ざ 夌尤以す以に 五 ○外吕三至 虎六の部二b 瓦分分二 對をのは一止 す燒は七\%の るき五七に後 含七一尤相攝 量残尤九當氏 こ 万幽\%す。 灰\% 世务なな ばはりる 五 三 其 六二 中

三五比

$\%$ 八

に无

住

相少

賞 b
東 亲 E 學 危 誌 第 二 t 战 
本

邦

產

䞡

蓦

용

$\frac{8}{8}$
$\frac{8}{8}$
$\frac{8}{80}$
$\frac{8}{8}$
$\frac{8}{8}$

の

成

分

に

就
1 器 放す 上

1. D置る述

ル周するの

内圄吕若如

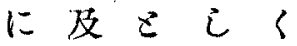

於びきェに

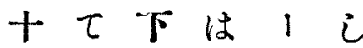

三

分

分

$>に$ 附の

ル乾着後

カ燥せ工散得力

口せ方、後た口

イるるテ少るイ

ト後のル量 $\boldsymbol{1}$

の其は

所熔濫 b另性

得融晶結口口状

點占晶 -

をなせフト

見り学は

百其少 $九$

に結り毒 ।

凡晶す加

八性制入ル

の 然ての

度部门一捚

位分了旦散

なる結 溶 琈

与。揓 晶 解 甚

出性せだ

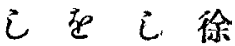

工顯め 々

キはたに

シ 万結

力 \& 後 晶
晶璗 入液後出口程斯

IIII $\iota$ 其 $\iota$ 度の

に其脱》残悉 フに如

移數色口液す学まく

し回せ、ににムでし

結、のてフ稀至を蒸て

十晶工め齐硫 b加發 -

$に 1$ 其么酸 $て へ し$ 旦

付テ 滤こ を止てて 精

せ心液分加的振後製

り振に離八其壍之せ

盪再して振しれる

液びて 振燙此に溶

寺純再燙》處純液

集結びこ口に結る

め晶微て、。晶㫦

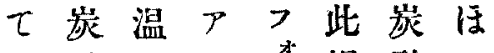

土酸に心竍操酸一

1 力於力

テリてロををり成

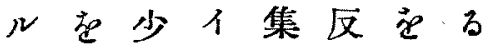

の加しドめ覆加心 大八く定でへく

部 $て$ 蒸之蒸 $\tau \tau$ 低 分分發れ餾溶飽温 を解已にし液充に

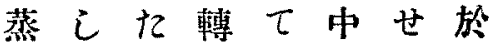

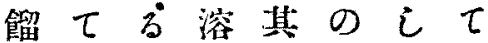
然後せ大 $r$ d餘 るじ少し部心直り 後工量内分力方溽

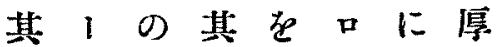
殘亏獸稀餾イ之こ 部儿炭 硫取ドれな をとを酸せをにら 結振加溶乃溶》邓 
用にェ一る次さ解上 ひ殆丰書第はし述 て ジ夜上に遂ての 速溶力 放 雷 透に之如 にり1置の明渌门く 結ざトせもと羁籃に 晶るルるのな化し

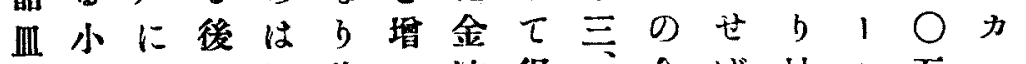
中部收壓鮮徐さ溶得、含ば抽ト䶭口 に㭆め㩁麗々 濾おて濾なにるるる複にルし内取だ 入る乾别え結に滴 7 監改力得にりは し。加 $匚$ 黄晶至加

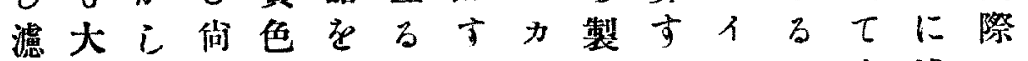
紙部てほの析是るロ造るだべ十述に 上はる三且出ににイイにき分べ如 の溶後枚つす於黄 ドさき所 $ア$ 亿何 不解 跙の光るて色の 溶せ酸潧澤に金の一。 解り々緍を至液溷部 殘依性間有る 渣りのにす其注を的 はて 沸”挑る 結 加生取 一溶湯み輕晶尔り 雨けよてき形止るて 回て $九$ 十小下める 少万再丒葉層七份れ 量。繥に片引放汇を のの晶水狀 㯰洼鹽 沸を世分をの方加酸 湯罡九第はるねね に折と去す制こ持性 てりせり此明き續の 洗滤るた結なはす水 山紙にる晶ら溶るに たを之上をざ液と溶
得故に其め

をに工重にキ 畭十量工ス 燥分 ス 公中 莨に一キスの 若抽磅シ 二厂 は得ル乾乃な 約は力燥抽る ○工口出程 二キ巵吕法度 八スドに \%のはの依で 巳約六にり抽 な る 问 三 二十 八六元分得 $\%$ 三四にら 死九抽乃 得方五出了 らる在在加 万人市試在 べりみ見 し 䈏た斿。 此なるるが 所り故に篇
事 京 化 學 을 詰 第 二 $+$ 九 帙 
物斯後鹽量の有 b沸よ熔量小結り。る 那質く盛にのと可更湯り融の葉晶

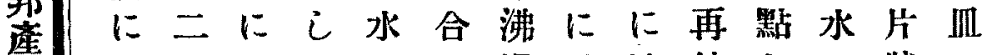
埌 あ種泡てにし湯稍溶結をに狀に 菪 らの發攝てててよ多け晶見ての入 草 ず金す。民洗少り量ざする洗結れ 田し”複。一ひ一再ののるるに涤晶て

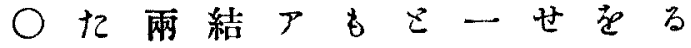
叹少尼 ○万回晶ハのき五る析光 度後監せ力は山九㣪出の क 離 三

種㤩

ह.

送 $P$ 得

の $\Perp$

成 分

召吅

就

$\tau \leqslant \tau$

の 抽

混出

合 $i$

た得

了 た

こる

$\sum>$

te

一 推

二 知

す人

万仡

には

足 單

弓 -

叉

に畭酸し口此其乃能せは

於燥含”侟揢至く b液

てせ有てドに融一水一の

畭るの此在得點六分書冾

燥与涨處上た一○を夜却

世の湯に述了六度除放す

るは飞得の量 $\bigcirc$ を置る

与淡熱た如甚乃示七後に

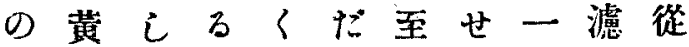

は色七沸に少一马旦過つ

一 ○愈湯 $i$ 六此乾 $i \tau$ 九光 $3 に \tau i$ 三結加 $\tau$ 鮮

亲澤溶溶金て度晶已結黄 乃なけけ複其のを少晶色 至きざざ監性。份攝をの

一結るるに狀の玨氏滤黄

九晶与部戀をと一一紙金

入形の分汇見な雨○上樣

度制は去七るる回 0 下光

に明集前之能。監度集澤

てなめ回をは

酸にめを

熔 らてに數ざ

融ざ一得回り

s 畭 $\tau$ 有

己る雨た籃乞

性燥一主

熔金回了酸に

9 $i$ 雨 $る$

沸七回輕

融複少。含依

湯其少き

後

滤

紙

間

に

懕

$i$

$\tau$

水

分

ze

拭

ひ

時

計

硝

子

上.

に

移

¿

$\tau$

工

$\neq$

シ

カ

I

ト

v

内

に

ス

n

置

け 
せカなる し口万述卜 めイ性 べ て

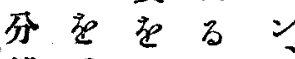
㒕悉利如 且々用く 精金江此 製複て等

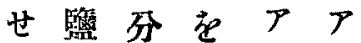
bに離一ミル 故鶖 す旦ンカ にじる金及口 此てよ複びイ 法而り䭆スド は吕他にコの

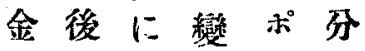
複其方じラ 離 䣱金法て ミ の複な其ン 精 罯 $し$ 等 等 製る依金の 䜿 り 複 瞳

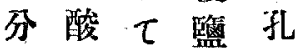
離含 前 散 飞有に沸大 をの述湯 藥 筆沸へにの 好湯记對丒 たるるす離 万方如了仡 8 數; 溶 既 の回乞解に に再 $匚$ 性 緒

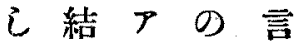
て晶儿暴に
質金知か斯複 ゙デる此 死複れなく留ンアに處 研罍ずる既にブミ熔に 究に刃もに相 $\varkappa^{2}$ 融”得 す相前多二賞との點た る違に量種す氏金一る 十尼な藇ののるの袙兵金

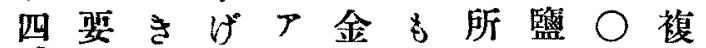
す。や゙複只謂に乃留 否る力籃其七又至は $p$ 二 を種亿分融不融六何 確のド賉點 點二な む金のしはン一度る 万複中得 $シ$ 即九のを に䜿にて方六黄の 住はるら令乃金に 先果佾急氏日至樣相

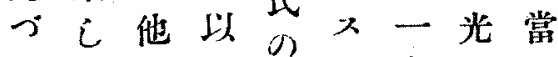
此 混比少二告我八了 合 $\exists$ 量種空亏度有 $\checkmark$ 入の ルテア

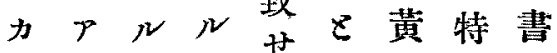
口ミカ力程色異及 インロロすすすのび Fをイイる光金諸 を入ドド滓複家 分二のをルな監の 離术存含力きは報 乙う在む吅正告 $\tau \equiv \bar{g}=19 に$ 份ンるとドはヒに

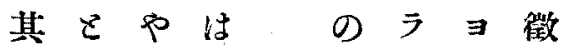
性の8確金1 万市
辣 京 化 學 욜 言 第 二 $+$ 九 帙 
本一世晶を以加了以淡て於b吕量便 邦るす呈上其にて黄他 $て$ 析をう利

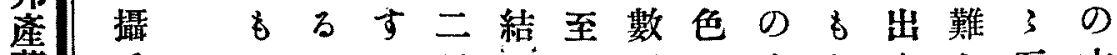

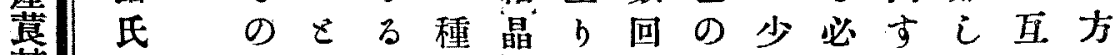

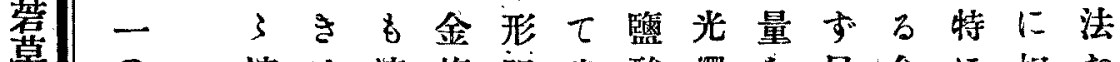
卓 0 熔は液複明佔酸澤を見金に相た 焉 0 十融黄冷整亮䚾含な混る複一混る 要度五點色却の.な溶有きせ如監旦じの

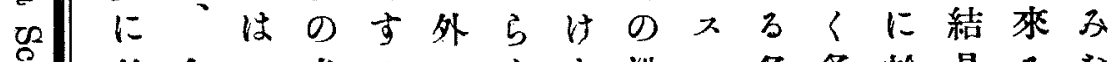
8 乾金二光るに方沸コ各各於晶るな 总燥複三澤こ最しし湯ポ自自てををら

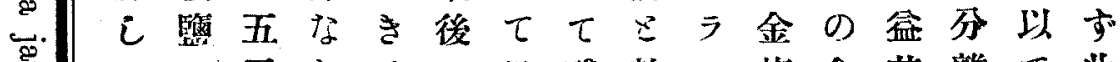
要ての历き只殘熱ミ複金其離 $て$ 此

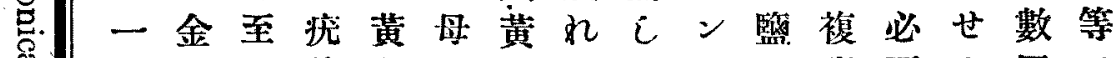

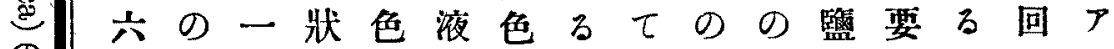
の $\bigcirc$ 含三にの上不る其金若はあ後再 戌乃量七集塊 b唀の水複干此り の結力 に至定度合之得明に溶籃党法而各晶口 就一量をすななのて葆に得にれ自をく 六示るるる結てよ相る於この反ト

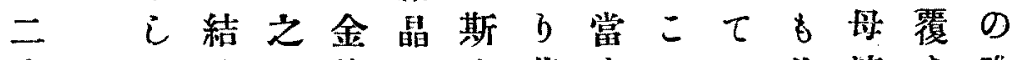
度。厂晶机複性く黄与を方此液す唯 に卜にに監物數金了を絕他をる一 於口鹽は質回樣も否對の蒸にの $\tau$ ピ $\tau$ 酸姆た沸光のれ的精墢あ分 熔ン攝合液る湯澤はすに製しら離 融の氏有温こをの殆分法てざ法 す金一のきこ以小ご 離若濃れな

一る 複 $○$ 沸間をて葉沸すく稠ば、る 監○湯は認取片湯 に度よ濃む据狀に 一にb厚る ひ結溶 致於再ののた晶け す。三油及るる をざ 乾再狀第得了 るはと各 る $\%$ めざ

二分な自各 と離せ党金 能のる純 複

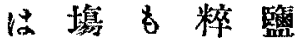
ず合のには こによ得 少 
稍をの斯

遠 理\% ?

き論よ熔导

に上万融

過の多點这已

之点九

nb 出六

籍多す乃

加! 諎至

に見化一

不出學九

思せ者八

議るの度

$\varepsilon$ 例實

世少驗 。

了加報の

處与告住

なざ等 幾

b 3 t回

己 8 見

济余方金

後のにの

に實此含

至驗篡量

b 數 合 te

此はに定

金理あ量

複諭与す

監上ざ

をのる

硫數

化 $\varepsilon$ 金江

水相の計

素距含算

る量上

8 t
(2) (1)

(3)

(2)

攝导

○

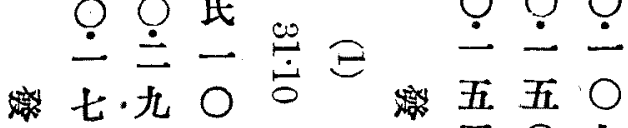

四 $\mathrm{Ot}$

- 0 O

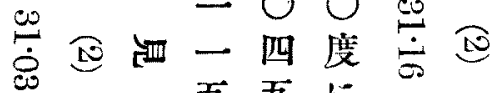

瓦瓭江

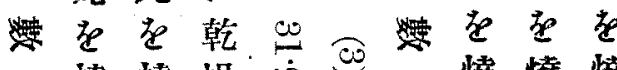

烇燒燥宫辽

き

$\tau \tau \tau$

O

$\dot{0} \dot{0}$ 九急萝

五八共了西

燒 燒 爟

ききき

$\tau \tau \tau$

三九

二八至

瓦一

0

$\dot{O} \dot{O} \dot{O}$

四四三

八七三

四 $\bigcirc$ 四

死死

のの九

のの の

$r 。$ 金金金

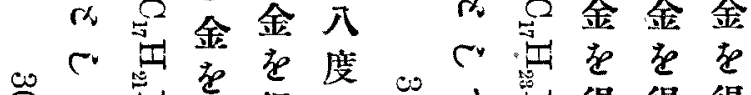

得得に些A硆得得得 t2 t2 t2

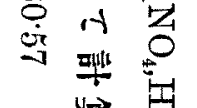

do 漹

क +

机机於

6

b $\tau$

熔

融

I

る

b

D
乘

京

比

學

․․․

志

第

二

$+$

九

帙

孛
四 
茛至引

知 3

万ᄃ $\stackrel{\infty}{0} \Xi$

に實

足驗薮悹

을.

:

の

成

分

に

就

$\tau$

理

論

t.

の

數 䜤

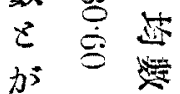

胳

致
せ

3

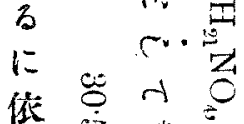

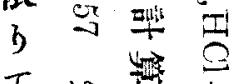

$\tau$ do 4

此金窇

複

鹽

の

殆

ぞ

純

粹

な
今 ミ三る残晶せ古以

(2) (1) 更 ド-金れをるるて

に氏二複る得に能分

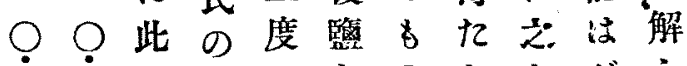
四二三スををのりをざし

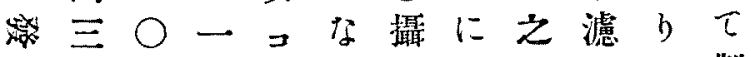

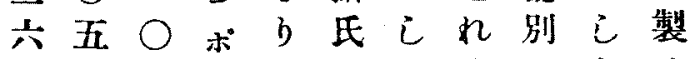
四三乃 死死至三つ○羽める以る。

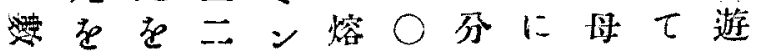
燒燒一の融度離最液再離 き己二金すにの早よび監 $\tau$ て 度複る乾難溶り之基

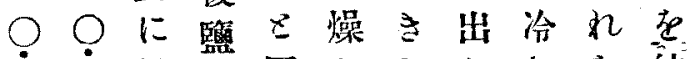
一 $\dot{0}$ 於に同已をし却を結 三三 三 關 時 $\tau$ 示盡後金 晶 三二熔すに其すし再複せ 五二融る㓺熔になび篮しし 旡死す埖し融足り少にむ ののる告く點ると量變る 金金金飞泡虎而思の をる複—發見しむ黄更的 得得籃致叶たてし金にに

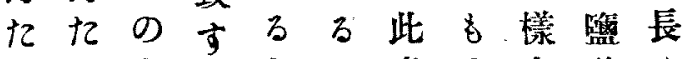
り口。金る存に處少光酸 をを認著にほ澤含放 永認め已沸容を有置 量め是〈湯易有の世

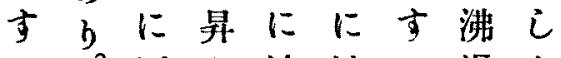
万。至b溶溶る湯。 $に \quad b \tau け け 小 と$ 到 $\tau$ 二小桃葉熱底 初一 $匚 5$ 片 $i$ 結 め $\mathrm{O} \tau$ 声狀 て乃殘しの精せ 至的て結製し 
水るに全夕含熔液結液中數 分 楆溶部口利融を晶即に回 を.め解白、別點集炭ち分の

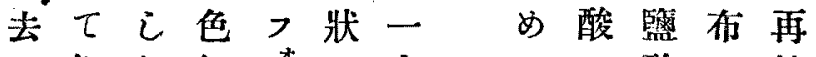
り細た細沓こ六エカ酸し結 一長る長么霹 01 小之晶 白の後のを 工針多針加之至七ル以のに經六量度 キ 狀量狀へれ- のて溶硫て的て

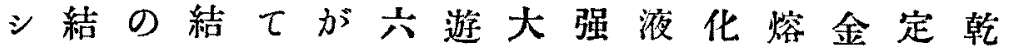
力晶水晶再徐二離部 $ノ$ 水融複量燥

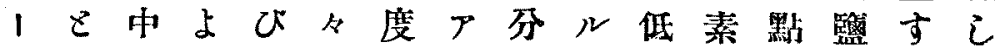
トなにり溶にのルをな温をのよるて ルる注成解結金カ蒸りに涌不りに一 内滤入れし晶複口餾性於じ戀遊至三

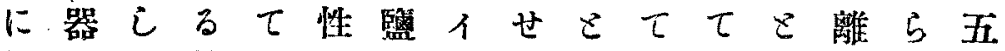

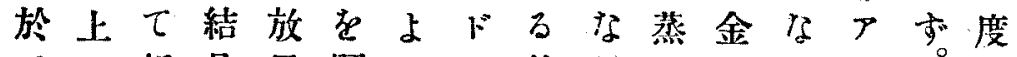
てに析晶置顯りの後し發をれN。正 十集出集す情性殘工京硫る力至 分めせ橉るした狀部了，化金口 にてしこを來る 乾母めなるるア や液精るは当 るこ製之比若 カ 後分すれ䡇已。 攝離る 氏せを成速! ド 一るきるか子は ○後は心にル工 ○滤純く結の 度紙白少晶揮 间色量已散心 於にののて 後の 七酎柔稀遂少揮 泩に加酒に量散 意てな精はの後 老溶金複 結ル存こ籃ド 晶をせなる゙の

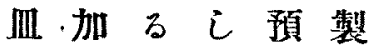
に八硫 $あ$ 造 移て化沈能 己振 水 港了 落燙素せ粉 晶己てて末 に其驅めと 付數除 世回乞濾乞 b. のた别置 振了记 出後其 $\tau$ 溶純滤 水 東 㬌 化 學 鱼 誌 第 = $+$ t 㭠 


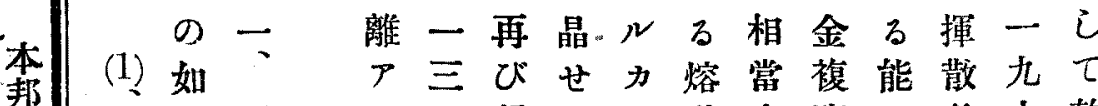

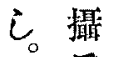
五 疑

垱

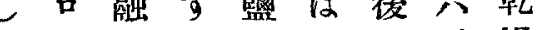

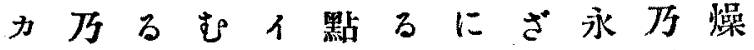
口至 るる

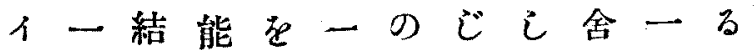
四 $九+F 三$ 晶 里 九 to 度 八分 に そ性す” 製 度 乾原出に

要 te 然

0 扰

八

度

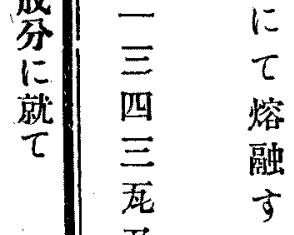

及

びマア

宸

酸

$\bigcirc$

四

六

四

二

西析
分

老 女

得

け

b

結

果

\section{能 熔}

は融

ざす

b 3

i。金

複

臨

は

其

量

極

め

$\tau$

少

量

な

b

i

霹

め

次
之

る

n

又

遊
ぞし金に製ドクす於

る報複全せは吃る

一告留篮了既、金熔

旦には純ににフ複融 溶依少粹向金 解る量なほ複么よ せにをら其罡監り るスるざ中の注得 る の ポめしりにしる はラ再なとも結ア 長ミびり くン之而ス心を力

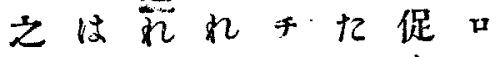
れ其をごアるすイ 在量分等 三 如 眿少解二ンく其は ふきi回の再目工 るこて 日金び的 1 こき遊に複之をテ きは離得留れ達ル は結アたにをすの 
0

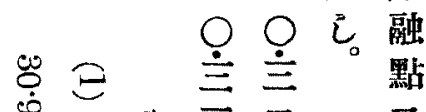
8

过㯰吉九

死厐 t存 燃燃

燒 焼

$i i$

$\tau \tau$

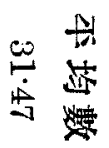

水 水

○?

든

$\equiv$

三一

的死死

‥

ツオ艺びひ

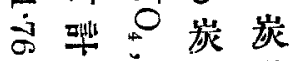

的酸酸

do$$
\text { 万ु }
$$$$
\text { の }
$$$$
\text { 槩 }
$$

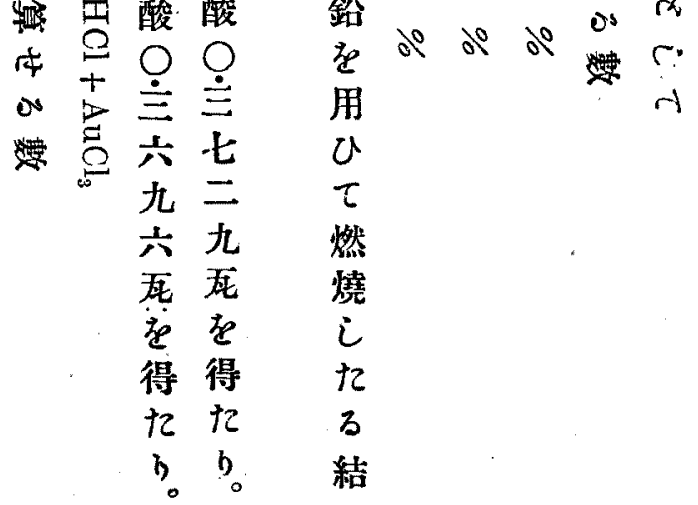$$
\text { 次三 }
$$$$
\text { 如熔口田。 }
$$$$
\text { 素（4) (3) (2) }
$$$$
\text { te }
$$$$
\text { 得 } \bigcirc \bigcirc \bigcirc
$$$$
\text { た产兰兰 學 }
$$$$
\text { \% }
$$$$
\text { 离这证 }
$$

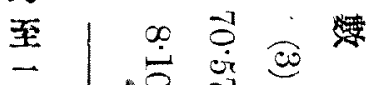$$
\text { b。交公 }
$$$$
\text { 五三0 }
$$$$
\text { 七七 七 }
$$$$
\text { 死死 }
$$$$
\text { を t数 }
$$$$
\text { デ 燃 燃 }
$$$$
\text { 1 焅燒 }
$$$$
\rightarrow i t
$$$$
\text { त } \tau \tau
$$$$
\text { 氏 水水 }
$$

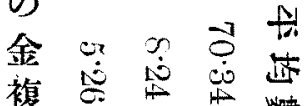

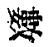

藋九立

氏二

法三五

死死 依及及

燃炭孷 燒 酸 酸

$i O 0$

六主

○八九

$\dot{0}=$

一共五

七无无

六を握

入得得

互九た

ब $b_{0} b$

咥 
有盪フク加殆容に莨 すし齐口へ民゙易酸宕

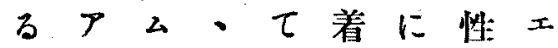
よルをフ飽色エをキ 万力合光充せ、な 己ロしムせざテるは

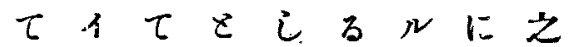
更ドク振虾層至れ九菅是較て究 にを口盪る至分らに

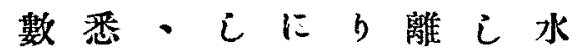

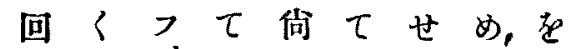
土之齐溶政止ざ之加

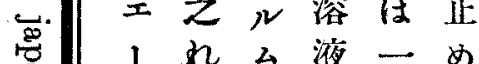

テにの中層斯をに䫶

है の 成 分 に 就 $\tau$

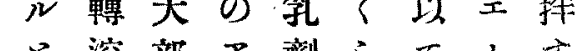
榕 部 $r$ 劑 振 せ 温 i $\tau \tau$ 精 期 製硫其をを酸 $匚 て$ 解 世酸殘悉以性 $\tau$ 振す る 溶部くての振璗其 後液に溶更水壍す水 低を硫出に溶しる溶 温分酸し之液各に液 に離々たれに部非に 一於せ性る在純の常稀 二 $て る の$ 後小結振に篦 旮蒸に水其分晶璗学酸

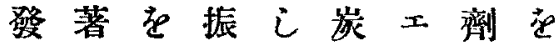
¿ $\tau$ 加盪 $\tau$ 酸 1 狀加 $\tau$ くへ》其力 容色て口各りルなて 積を振、、ををにり微
樂を宕に莨 局以根は若 方ての其草曰 规最成結の 定分果成 の其を果分 十萣當比研 工得す燕は峛 莨キたる用之 菅スるのにれ ๘当必堪に ₹使 の要ゆ ス用こある終 のせ思るや 研り考の否を せみや告 るなをげ 上ら制て b定 b

其 寸而 $\tau$ 製 余品にて はたは今苦 其 る 勢 材莨ひ結 料宕現論 こ根にを 工探下 $\tau \neq$ 用卞 第入 己に 三㠿つ當 改研 3 b 正究 あ $\tau$ 日方了一 本方暻方 
性以監乃於七世次丰のた洷取以を 牀上飞至て

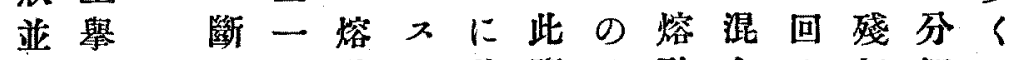
びげ定四融千其監約融合少部解己。 に來す五すア主基 ○點ア量をして 其b 心度るミな竞は心の結て之

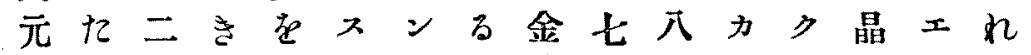

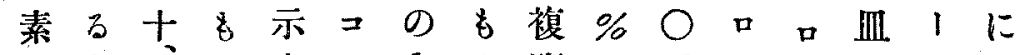
分金、のすボ金の監に乃颃ににテ少 析複結了所ラ複はに相至ドフ移心量

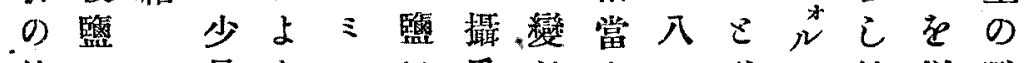
結の論量りンに氏じす一殆ム結以獸 果性をこの相一て度ごに晶 $て$ 炭 よ牀. 得て金富 $\bigcirc$ 朁を同溶せ振を b熔たと、複す $○$ 示樣かし燙加。

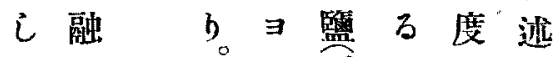
$\tau$ 點 真金 宕 草 含 ○) 量 第 及 一 び

0) 金

7 複

2 㲯

力

口 $b$

1 得

ド

蚂了

七遊

離

又 鹽

千 基

$>\sigma$

又雨鸟に心

千三の乾 た

ア回に燥る

ミ位 $已$ 後方

ン熔 $\tau$ 一法

の融省六に

少點 汪○依

量を此厉 b

を見外至て

混 得に一此

世当二六金

子量一三複

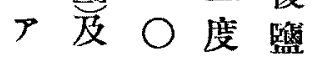

卜び乃にを

口熔至於精

ピ融二 $\tau$ 製

二 點 一慾 且

の-二融っ

金三度す分

複五几了離 ¿にiめiへ

工放た其 $\tau$

$\neq \tau$ 置 b數 脫

ス工其斯回色

一

磅シ結の振

よ力晶如盪め

b、せく工其

のトしし I 滤

所 $⿻$ め $\tau$ 液 得丙九得几农 はにるれを再 一於るる集び 三 $厂 \gamma$ め純 二十は結 馛分莨力其晶 小に宕口大㞸 了乾草不部酸 故せよド分カ にる 当をり 工る得少餾を
東

京 化 學 會 誌 第 $=$ $+$ 九 帙 
の厂斯外次 コ份る此又第ン離第基 ミ

用ン莨量莨レ此く二トのる,

丁て有は 载基すと

のにるョ

原其こ

料主こ

並成を广

び忽 知

にはる。

七 $上$ に

$\exists \quad \exists$

i

入八

$\tau$

葉 千

ををは

基含 工

水有 $\neq$

溶吉

液 万一

のに磅

䖝過中

石引゙?

彩声

を。 万

呈至

す

万

?

d

b

i

$\tau$

x
複

監

の

性

狀

己

其

熔

融

點

¿

te

見

$z$

に

此

i

b

i

$\varepsilon$

雖

\%
こカア量る

飞曲亲こ 